\title{
Online Social Networks and the New Organizational Spaces
}

\author{
Cintia Rodrigues de Oliveira Medeiros', Cristiane Betanho², Jacquelaine Florindo Borges 3 , \\ Rodrigo Miranda ${ }^{4}$,Verônica Angélica Freitas de Paula ${ }^{5}$
}

\begin{abstract}
We analyzed the 'virtuality' of the social space and the boundaries of organizations from the emergence and dissemination of online social networking. The purpose is to identify how the use of social networks by 10 Brazilian companies enables the redefinition and expansion of organizational space. For the analysis of the data, we used the theory of social space of Lefebvre (2004), which defines three moments of space social production: the imagined space, the lived space and the perceived space. The methodological qualitative approach is done by document analysis from the websites of the companies. We show that the organizational space has new contours with the adoption of online social networks and we analyzed four spatial metaphors: the square, the museum, the temple and the market.
\end{abstract}

Keywords: metaphors; social networks; organizational space; organizational strategy.

Avenida João Naves de Ávila, 2 I 2 I - sala IF2 16 - Campus Santa Mônica. CEP: 38.408-I 00 - Uberlândia/MG. Phone: (+55)3432394I32

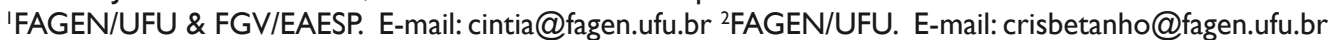

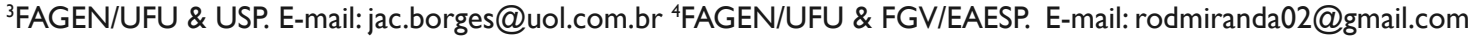
${ }^{5}$ FAGEN/UFU. E-mail:vafp@terra.com.br 


\section{Introduction}

[...] There is no separation between "reality" and symbolic representation. In all societies, humanity has existed in a symbolic environment and worked through it. Therefore, what is historically specific to the new communication system, organized by electronic integration of all media, from graphic to sensorial type, is not to lead to virtual reality, but to build real virtuality (Castells, 2007).

Shift. Rupture and discontinuity. Internet and Information Technology. These words characterize society and the business world in the 2 Ist century. Information technology (IT) has developed in such a way that its use not only promotes reframing, but also creates new opportunities and new environments. Just as in society in general, a "real virtuality", in the words of the author of the quote, is outlined in businesses, changing companies' products, processes and operation fields.

In the quote, the author defends the existence of a symbolic environment. In the same line of thought, Starbuck (2007) gives the organization concept a mythical character, because for this author, this concept implies the possibility of distinguishing the organization and its borders. However, as the author argues, these boundaries are becoming increasingly blurred and ambiguous due to technological changes, caused mainly by the advancement of IT, which modify the characteristics and properties of the traditional concept of organization.

Online social networks have broadened the options for organizations to interact with different target audiences in the space created by the web. They give organizations greater popularity and reinforce their presence in society as promoters of a collective participation and collaboration model. However, this model is questioned for not enhancing the social transformations which would be able to change the basis for the exercise of power in society (Dijck and Nieborg, 2009; Rheingold, 2004).

In this article, we analyze the websites of the Biggest and Best Companies from the 2010 Exame magazine yearbook, aiming at identifying how the use of social media by companies enables the redefinition and expansion of the organizational space. This concept underwent changes in different currents of organizational studies. The deterministic and rational view of space, characteristic of classical approaches, gave way to a relational and constructionist vision, thus increasing the very concept of what the organization is. The study is guided by a qualitative approach and data collection is conducted by documentary research. In the content analysis of the material collected from the websites of the companies who were the object of this study, we identified the various interactive features deployed by the companies in online social networks.

The paper is structured in five parts, including this introduction. Initially, we present the concept of organizational space and the implications of virtualization on the very notion of space.Then, we discuss aspects of virtualization in the spaces created by the use of online social networks. Following this, we describe the methodological procedures and the results of the analysis of the corporate application of online social networks to redefine and widen their performance. A section with closing remarks finishes the paper.

\section{The concept of organizational space and the virtualization process}

Contemporary science portrays a real and complex world, in which the certainties of deterministic science give way to the emergence of new concepts. For Harvey (1996), individuals and institutions dominate the organization of space and its production in order to establish a control system over the occupants of these spaces. Capitalist society needs a system of continuous feedback in the quest for profit, so we can say that the control of time and space is achieved with the control of capital (Harvey, 1996). The control of time, space and capital grants and maintains political power in the public or private sphere, influencing the way in which social and productive relations are established (Harvey, 1996).

Regarding organizations, the concept of space was first introduced by Management Classical approaches, with the conception of space being discussed as something determined and precise which is set in accordance with the organizational project and work needs (Fayol, 1990; Taylor, 1990). This project describes and determines the spaces in which human interactions should happen. In these approaches, the space is associated with the organizational structure, chains of command and subordination, workflows and the places in which tasks must be performed. Therefore, these spaces are places of geographical, personal and social reference.

However, since the late twentieth century, models of work organization that separate organizational space from other spaces are transformed by IT that resizes the spaces required for the development of the tasks and also the organizational structure. Technological advancement creates new concepts of time and space when it determines that being present does not necessarily mean physical presence (Brocklehurst, 200I). Social networks leverage the combination of various communication, information transmission, interaction and monitoring tools (cell phones, iPods, tablets, notebooks, wireless connections through radio, satellite, etc). For an organizational or work interaction to be viable, people do not need to be in spaces or locations defined by

ISSN: 07 I8-2724. (http://www.jotmi.org)

Journal of Technology Management \& Innovation (c) Universidad Alberto Hurtado, Facultad de Economía y Negocios. 
rigid physical boundaries. An illustration of this is the fact that someone can have a work meeting during an international flight with a person who is playing golf or doing their morning run.

Thus, IT and its applications not only reshaped urban space (Castells, 2007; Giddens, 1984), but also the very notion of space centered on a classical view of limits and boundaries, more easily identifiable. In fact, the application of the concept of space virtualization in the organizational context dismantles the classical view of a company based on structures and hierarchies (McAfee and Brynjolfsson, 2008). The deterministic and rational space view, characteristic of classical approaches (Fayol, 1990; Taylor, 1990), gave way to a relational and constructionist view (Hatch, 1999; Kornemberg and Clegg, 2004), thus, widening the concept of what the organization is.

The virtualization process generates another perspective for understanding the organizational space when combined with the understanding that, after all, the organizational spaces are appropriations that result from organizational dynamics and become physical representations of discursive constructions in the different stages of existence of an organization (Halford and Leonard, 2005). From this perspective, IT enables the organizational space to be created, maintained and transformed by virtually and symbolically established interactions. When applied to intra and inter-organizational activities, IT proved capable of providing companies with new planning, communication, organization and control tools, besides providing new business models.

McAfee (2006) coined the term Enterprise 2.0 to refer to companies whose products were originated in environments characterized by: (a) freedom and autonomy - where people meet as equals and do whatever they want on the work platform, and (b) participation and collaboration - no barriers for participation and cooperation so that, over time, unplanned and undirected interactions would produce patterns and structures that enhanced participation and collaboration.

Enterprise 2.0 technologies bring new concepts to the understanding of organizational space according to the elements that characterize this category of company described by McAfee (2006):

a) Search - you need to find what you are looking for, which is not always easy on the intranet.

b) Links - in companies, people should be able to create links.

c) Authoring - through blogs and wikis, people satisfy their desire to create content. The intranet is constantly being updated by the work of many. d) Tags - classification of content facilitates the use on the intranet. Tags express the relationships and structures of content that people use.

e) Extensions - These are the identifications of preferences based on accessed links. For example: "if you like this, then you will like that".

f) Signals - warnings about new content of interest added, such as RSS type messages.

These elements promote significant changes in the companies by generating more information, speeding up communication and generating alternatives for creating value for the company and its stakeholders. They also reduce cost by making organizational processes more flexible to the strategic need of decentralizing decisions and delegating authority and responsibility. These elements enhance new spaces for organizations because they allow interaction with various types of users: current or potential consumers, employees, suppliers and partners. These elements, combined with other information technologies, also enable interaction to be pursued not only by the company, but also by all who have an interest in the existence and activities of the company. This allows them to express their satisfaction or dissatisfaction, interests, needs and values. Thus, conceptually, ITs are capable of producing, within companies, an extended space to perform their activities.

\section{Organizational space and social networks}

The term Web 2.0 first appeared in a brainstorming session, when it was coined by O'Reilly to refer to new sites and applications that continually emerge (Cobo Romaní and Pardo Kuklinski, 2007). O'Reilly (2005) defines Web 2.0 as a platform "spanning all connected devices; Web 2.0 applications are those that make the most of the intrinsic advantages of that platform: delivering software as a continually-updated service that gets better the more people use it, consuming and remixing data from multiple sources [...]". The Web 2.0 platform goes beyond the metaphor of a Web I.0 page as it potentiates creating network effects through a "participation architecture", which allows users to upload their own data and services. This author noted that companies surviving the collapse of the Internet bubble in the early 21 st century had something in common. He termed this Web 2.0 to differentiate it from Web I.0.

Web 2.0 can be seen as a new space in which social relationships occur, because for Cobo Romani and Pardo Kuklinski (2007), this is a technical-social phenomenon, which therefore includes the relationships that companies have with their various audiences. Studies on the use of Web 2.0 emerged in the 2000's (Dennison, 2006; Hinchcliffe, 2006; Hof, 2006), revealing the importance given to the adoption of this technology in various fields of knowledge and prac-

ISSN: 07 I8-2724. (http://www.jotmi.org) 
tice, for example, Boulos and Wheeler (2007) in the field of education and health. In a survey of the 500 largest companies listed by Fortune magazine in 2005, Lee, Hwang and Lee (2006) studied the use of corporate blogs and showed how this technology allows maintaining control over an alleged autonomy that is given to these tools.

In 2007, McKinsey \& Company (Bughin and Manyika, 2007) conducted a study on the use of Web 2.0 by companies. The results of this study show that most participant executives consider Web 2.0 a strategic tool for the company and plan to increase their investments in these applications. Accordingly, Young's study (2007) shows that the ClOs (Chief Information Officers) participating in the survey said they had adopted one or more Web 2.0 tools (Figure I) and see value in their use.

Murugesan (2007) notes that, although Web 2.0 tools are seen as a promise to transform the use of the web, many professionals in the fields of IT and business remain skeptical about their value. However, the benefits generated by the use of these tools are varied, as Murugesan (2007) himself points out: they (a) provide a rich and responsive interface to the user, (b) facilitate the collaborative creation and modification of content, (c) allow the creation of new applications and combinations of Web applications, (d) allow the combination of data and information from different sources, (e) establish social networks between people with common interests and ( $f$ ) provide a basis for collaboration and help aggregate collective intelligence.

Thus, Web 2.0 technologies reconfigure various forms of organizational space by enabling the company to establish relationships from their goals and functional areas with its many stakeholders: customers, employees, investors, suppliers and others. This reconfiguration of space became widespread through one of these tools, online social networks.

The use of online social networking is a practice adopted by one in every seven people on the planet, according to a survey of Insights Consulting, published in the Época magazine (Mansur, Ferrari and Guimarães, 2010). Huge virtual

\begin{tabular}{|l|l|}
\hline \multicolumn{1}{|c|}{ Tools } & \multicolumn{1}{c|}{ Description } \\
\hline Blogs & $\begin{array}{l}\text { (short for Web Logs) online diaries hosted on a website and often distributed to other } \\
\text { sites or readers using RSS (see below) }\end{array}$ \\
\hline $\begin{array}{l}\text { Collective in- } \\
\text { telligence }\end{array}$ & $\begin{array}{l}\text { Refers to any system that seeks to achieve the expertise of a group rather than an indi- } \\
\text { vidual for decision-making. Technologies that contribute to collective intelligence include } \\
\text { collaborative publishing and common databases for sharing knowledge. }\end{array}$ \\
\hline Mash-ups & $\begin{array}{l}\text { Aggregations of online content from different sources to create a new service.An example } \\
\text { would be a program that takes lists of apartments from a website and shows their loca- } \\
\text { tions on Google maps. }\end{array}$ \\
\hline $\begin{array}{l}\text { Peer-to-peer } \\
\text { networking }\end{array}$ & $\begin{array}{l}\text { Referred to as P2P, it is a technique for sharing files (music, video or text) either over the } \\
\text { Internet or in a closed user group. Unlike the traditional method of storing files on a serv- } \\
\text { er - which has become a problem if several people try to access it simultaneously - P2P } \\
\text { distributes files to multiple machines, often the users themselves. Some systems retrieve } \\
\text { files by collecting and assembling small pieces of information from multiple machines. }\end{array}$ \\
\hline Podcasts & $\begin{array}{l}\text { Audio or video recordings - a multimedia blog or similar. They are often distributed } \\
\text { through an aggregator like iTunes. }\end{array}$ \\
\hline RSS & $\begin{array}{l}\text { Really Simple Syndication - allows people to register online for the distribution of news, } \\
\text { blogs, podcasts, or other information. }\end{array}$ \\
\hline $\begin{array}{l}\text { Social } \\
\text { working }\end{array}$ & $\begin{array}{l}\text { Refers to systems which allow members of specific sites to learn about the skills, talents, } \\
\text { knowledge or preferences of other members. Commercial examples include Facebook } \\
\text { and Linkedln. Some companies use these systems to help find experts. }\end{array}$ \\
\hline Web services & $\begin{array}{l}\text { Software systems that make it easier for different systems to communicate with each } \\
\text { other automatically when passing on information or conducting transactions. For example, } \\
\text { a buyer and a vendor can use Web services to communicate by internet and automatically } \\
\text { update their inventory systems. } \\
\text { LikeWikipedia, these are systems for collaborative publishing. They allow multiple authors } \\
\text { to visit and edit a set of linked pages or online document. }\end{array}$ \\
\hline Wikis &
\end{tabular}

Figure I.Web 2.0 tools used by companies. Data based on Bughin and Manyika (2007).

ISSN: 07 I8-2724. (http://www.jotmi.org)

Journal of Technology Management \& Innovation (C) Universidad Alberto Hurtado, Facultad de Economía y Negocios. 
communities are organized by sites like Facebook, Orkut and Twitter, amounting about I billion people. In a survey conducted by Consumer Reports, they found that of the 20 million minors active on Facebook, 7.5 million are under 13 years of age (the minimum age to use the service), and of these, 5 million are less than 10 years old (JFSP, 20I Ib).

In these communities, interactions range from simple information exchanges to the emergence of stars, activists, more active citizens, vigilantes and controllers, voyeurs, friends and enemies, and companies interested in extending their business to this population. However, the technological ambiguity is also present in social networks, because for some people, the possibility of disconnection from the network implies in exile from society itself, generating new emotions: the fear of missing out; the sense of importance and power when you get a message of an idol or celebrity, who uses networks to stroke the ego of his or her fans; exposing private details in the pursuit of social approval; impotence at not being able to be part of everything that is being circulated on social networks (Capriglione, 20I0; Demetrius, 20I0; JFSP, 20I la). Social networks become, therefore, the space of human capacities and frailties.

The ambiguity is also present in the corporate use of social networks. While most companies restrict the use of social networks, some stimulate it and others even create their own social networks. Research conducted between February and March 2010 by the consulting firm Robert Half with 3,052 executives worldwide showed that $38 \%$ of employees can use sites like Facebook, Linkedln and Twitter without restriction, $37 \%$ do not have permission to access these sites and $24 \%$ can access them with restrictions (Hill, 20I0). In Brazil, the 227 executives surveyed reported that $44 \%$ use social networking sites without restriction and $26 \%$ do not have permission to access those sites. Another survey by consulting firm Manpower shows that the main concern of the companies $(63 \%)$ about the use of social networks by employees is that it will lead to lost productivity. This "corporate fear" is followed by another: $33 \%$ indicate a concern about protecting sensitive information and ensuring the company's reputation. Other companies, however, have offered training to their employees so they can use information (texts, images and audio recordings) obtained from social networks productively.

Some companies encourage the use of social networks and create their own networks, host employee blogs on their servers and have thousands of wikipages edited collaboratively by staff. When they identify content published by its employees that may jeopardize the company's reputation or content regarding sensitive and restrictive information, it is common for them to remove videos and texts from sites. The creation of communities in an internal company net- work is also an alternative used by companies to develop teamwork, corporate culture, initiative and autonomy. The subjects and themes on these internal networks can go beyond the professional life and work in the company, providing an alternative for the exchange of information and personal experiences (Hill, 20I0).

Social networks are also seen as a window of opportunity to win over consumers (Cornachione, 2010). With the use of text, audio recordings, pictures, games and challenges, companies can establish a playful interaction with their actual and potential customers, trend setters and geeks. Nike innovated by installing a chip in the sole of a running shoe it sells. Through this chip, the information is transmitted to an iPod or a Nike wristband that transfers the data to a Nike Web site. From these data, a person can have information about the distance he or she ran, workout history, comparison with other runners, participate in challenges and create running groups regardless of where people are. The condition to remain part of the group is to continue using and buying the shoes of that brand.

Customer care services have been replaced by social networks, as some customers prefer to relate with the company in this space (Cornachione, 2010). The corporate use of programs that seek information through keywords about what is being said about the company is increasingly used. With these programs it is also possible to identify users that share doubts and seek information on various subjects. With such information, the company's team of consultants interacts with that person, presenting the solution to his or her problems and answering questions regarding health, beauty, entertainment, among others. The information captured in social networks is not only a source of guidance for sales, but also for the conception of new products. In the space created by the company, social network users can post suggestions for new products, reviews of products in development, they may test newly developed products and can demand the return of products withdrawn from the market.

Finally, the interaction of the company with customers in social networks is not only characterized by opportunities, but also the risk of losing control over the company's actions, since it becomes more vulnerable by being exposed to more diverse audiences. The actions, messages and decisions of the company are received, interpreted and even manipulated by these groups. With access to resources that enable low cost compositions, voiceovers and production of their own images and audio, web surfers can also develop content on social networks which were not predicted by the company. This content can be unexpected and surprise managers, generating great impact on the strategies of the company. 
An example, although not that unpredictable, occurred with the company Arezzo that produces shoes, handbags and accessories. They launched a collection called "Pelemania" (fur mania) which featured some products that used fox fur. After a declaration of the president and founder of the company explaining that "all brands" were using the exotic furs and the ones used in the collection had been "properly regulated and certified" (JFSP, 20I Ic), the board of the company withdrew the collection that used fox fur from all stores in Brazil. The subject and the company ranked among the ten most commented on the social network Twitter and protests have spread across the Internet.Although the company reaffirmed its commitment to sustainability in a microblog, Jessica Ferreira asked: "Now \#arezzo announces that they will remove the products from circulation. Big deal.Will they resurrect the animals too, or not?" (Enlists, 20I I).

However, the fact is that a company can be inserted in social networks without its knowledge or consent, as was the case with Activia, a product for regulating the intestine produced by Danone, which has been the target of jokes on Twitter (Cornachione, 2010). Some similar situations also generate distrust and criticism of social communities, such as when they understand or suspect that the company itself posted a controversial video, image or text on purpose, as part of their marketing strategy.

\section{Methodology}

We conducted this research using a qualitative approach and collected data through document research. To identify how the use of social media by companies enables the redefinition and expansion of the organizational space, we researched the websites of the companies listed in the annual "Biggest and Best" list from Exame magazine published in Brazil in 2010. Since we could not research all listed companies, amounting I,500, we selected the top 10 companies in the ranking of the largest annual sales criteria used by the magazine.

For the analysis of data presented on the websites of the companies selected for this study, we used content analysis according to Bardin (1979), seeking to identify the use of social networks by these companies and its implications in the concept of organizational space. The results of this study were grouped into categories according to the research results of McKinsey \& Company (Bughin and Manyika, 2007), which identified the purposes for which companies use Web 2.0 technology: (I) interface with users, (2) interface with suppliers and partners, and (3) manage internal collaboration.

\begin{tabular}{|c|c|c|c|}
\hline \multicolumn{2}{|r|}{ Company } & Sector & Social Network \\
\hline I & $\begin{array}{l}\text { Petróleo Brasileiro SA } \\
\text { PETROBRÁS }\end{array}$ & Energy & $\begin{array}{l}\text { www.petrobras.com.br } \\
\text { Youtube, Twitter, Facebook, Flickr }\end{array}$ \\
\hline 2 & Petrobrás Distribuidora S.A & Wholesale & $\begin{array}{l}\text { www.br.com.br } \\
\text { No access to social networks }\end{array}$ \\
\hline 3 & Volkswagen do Brasil & Auto industry & $\begin{array}{l}\text { www.vw.com.br } \\
\text { No access to social networks }\end{array}$ \\
\hline 4 & Vale S/A & Mining & $\begin{array}{l}\text { www.vale.com.br } \\
\text { Youtube, Twitter, Facebook, Orkut, Linkedln }\end{array}$ \\
\hline 5 & $\begin{array}{l}\text { Companhia de Bebidas das } \\
\text { Américas AMBEV }\end{array}$ & Consumer goods & $\begin{array}{l}\text { www.ambev.com.br } \\
\text { Twitter,Youtube, Flickr }\end{array}$ \\
\hline 6 & Fiat Automóveis & Auto industry & $\begin{array}{l}\text { www.fiat.com.br } \\
\text { No access to social networks }\end{array}$ \\
\hline 7 & $\begin{array}{l}\text { Carrefour Comércio e In- } \\
\text { dustria }\end{array}$ & Retail & $\begin{array}{l}\text { www.carrefour.com.br } \\
\text { Twitter }\end{array}$ \\
\hline 8 & Shell Brasil Ltda & Wholesale & $\begin{array}{l}\text { www.shell.com } \\
\text { No access to social networks }\end{array}$ \\
\hline 9 & $\begin{array}{l}\text { Telecomunicações de São } \\
\text { Paulo AS }\end{array}$ & Telecommunications & $\begin{array}{l}\text { www.telefonica.com.br } \\
\text { No access to social networks }\end{array}$ \\
\hline 10 & Vivo S.A & Telecommunications & $\begin{array}{l}\text { www.vivo.com.br } \\
\text { Facebook }\end{array}$ \\
\hline
\end{tabular}

Figure 2. Companies selected for analysis and social networks involved.

ISSN: 07 I8-2724. (http://www.jotmi.org)

Journal of Technology Management \& Innovation (c) Universidad Alberto Hurtado, Facultad de Economía y Negocios. 


\section{Results}

The first step in the analysis of how organizations are using social networks was to identify, from the companies' websites, which social networks they belong to. Since it is easy to include profiles in social media, we chose to analyze social networks through the access provided on the company's website. In Figure 2, we present the top ten largest companies highlighted by the annual list according to the criterion of annual sales, their internet addresses and social networks in which they participate.

The next step was to access the social networks of the company to identify how they are used. At this stage, we favored the three categories chosen to guide our analysis: (I) interface with users, (2) interface with suppliers and partners, and (3) manage internal collaboration.

The social networks identified are: Youtube, Twitter, Facebook, Flickr, Linkedln and Orkut. After identifying the social networks used by the companies, we analyzed their contents. To organize our analysis, we grouped the information according to the network (Figure 3):

The companies analyzed did not make intensive use of social networks. Twitter is the most used one. We describe below how each type of social network is used by those companies.

\section{Youtube: "Promote yourself"}

Youtube is a network that allows members to upload and share digital videos and also create a relationship network with friends. The site is accessible to any visiting user, who can access and download videos and post comments. The membership option allows members to share videos with restrictions among them.

Vale participates in this network since 2005 , has 45 I subscribers to its channel and has no friends. The profile has six comments posted, all of them with compliments to the channel and one comment from an employee who makes no reference to the channel: "I am very happy for Working at Vale SA". The presentation of the profile describes it as: "Vale is a pioneering mining company that works with passion, transforming mineral resources into essential ingredients for people's day-to-day lives".

The profile of Amber was created in 2010 , has 122 subscribers and 14 friends. The 4 comments posted by the public are compliments to the channel and the company for their marketing actions. There are 179 videos posted by the company about advertising campaigns, socio-environmental projects and company sponsored events. Some videos are intended to interact with the users, as is the case with commercial "Camelão com defeito" in which the company puts a question at the end and asks the users to post comments. In this case, four answers were posted, which do not refer to the company.

Petrobrás is a Youtube member since 2009, has 658 subscribers and no friends. 87 videos are grouped into nine playlists: (I) Our Stories - videos about the social, environmental and technological accomplishments of the company, (2) Biomaps - videos about the project where the company aims to know and map the wealth of fauna and flora, (3) Careers - a series of stories and testimonials of the company's employees from different organizational levels, (4) Inside technology videos about the technological capabilities of the company in the creation and development of products, (5) Petrobrás up close - videos about cultural projects sponsored by the company, (6) Preserving the environment - environmental projects sponsored by the company, (7) Promoting citizenship - social projects sponsored by the company, (8) Valuing culture - cultural projects sponsored by the company, promoting access to cultural hallmarks and the assertion of Brazilian identity and (9) Moving sport - sporting events sponsored by the company.

The video played when you access the Petrobrás channel, entitled "Nós do Morro - A vida levada pela arte - Petrobrás" (Us from the hill - life driven by art), has 7 comments praising the company and the project sponsored by the company. One of them stands out by the comparison made:"Congratulations Humanity". The Biomaps playlist has the following

\begin{tabular}{|l|l|l|}
\multicolumn{1}{|c|}{ Rede } & \multicolumn{1}{c|}{ Gênero } & \multicolumn{1}{c|}{ Empresasqueutilizam } \\
\hline Youtube & Video Sharing & Petrobrás,Vale,Ambev \\
\hline Twitter & Microblogging & Petrobrás,Vale, Ambev, Carrefour \\
\hline Facebook & Relationships & Petrobrás,Vale,Vivo \\
\hline Flickr & Photo sharing & Petrobrás, Ambev \\
\hline Linkedln & Professional contacts & Vale \\
\hline Orkut & Relationships & Vale \\
\hline
\end{tabular}

Figure 3. Social networking and user companies.

ISSN: 07I 8-2724. (http://www.jotmi.org)

Journal of Technology Management \& Innovation (c) Universidad Alberto Hurtado, Facultad de Economía y Negocios. 
presentation:"Being present in many environments, knowing and mapping the richness of its flora and fauna is a unique experience that Petrobras wants to share with you".

\section{Twitter:What's happening?}

Twitter, as well as being a social network, is also a server for microblogging, which allows users to send and receive, free of charge, personal updates via the network itself, by SMS and specific management software. User messages are displayed in real time and sent to followers who have subscribed to receive them.

When accessing the twitter link on the website of Petrobrás, we found the "Petrobrás Blog", which is the company's corporate blog, Facts and Data and network users. There are 2,637 tweets (instant messages), 2,463 following, 43,276 followers and 1,517 listed. The content of the tweets are of different natures: release of projects, cultural, social and sporting events, recent agreements signed with companies, clarification reports about events at the company, partnerships with institutions, awards obtained, information about the company's performance, promotions, among others.

Carrefour Twitter has I,634 tweets, 9,425 following, I I,019 followers and 368 listed. The content of the messages are product offers, discounts and sales. Some messages are sent to users who made requests and the company asks them for a way of contact.

The Amber profile on Twitter, @ambevbrasil, has 2,958 tweets, 4,468 following, 9,227 followers and 222 listed. The content of the messages is varied: promotions, recruitment programs, links to the company's ads, promotion of events and projects sponsored by the company, the company's stories. Besides that, the company interacts with users, thanking them for suggestions received.

Vale's Twitter, @VALE_Carreiras, has 390 tweets, 9,916 following, 11,313 followers and 336 listed. The messages are varied, covering the accomplishments and achievements of the company, investments, social projects sponsored, work and career opportunities in the company, supplier relationship programs, awards received, training courses and professional qualifications. Interaction with users is rare, one of them a thanking for supporting one of their initiatives, "Thank you. Thanks to your support, we have donated over 2 million reais (Brazilian currency) to the victims of the storms in the state of Rio de Janeiro".

\section{Facebook: "What's on your mind?"}

In Facebook, users can join one or more networks, such as specific groups, and that is an opportunity to connect to friends and make new friends. In this environment you can upload videos, pictures, texts, links, send messages, post comments, and also participate in chats. Facebook offers several features that enable interaction: marketplace (users can place ads), poke (users can poke friends), wall (users can post notes and communications), presents (users can send virtual gifts to friends) and like (the user can recommend the site).

The Petrobrás Facebook has 6,45I user recommendations. As for content, on the wall, the company posts videos, pictures, links to news about the company's performance and the social, environmental and cultural projects sponsored by the company. The users' posts are numerous and of different natures. There is interaction between users and employees and non-employees, as is the case with this post:"Hello guys, I'm from Dom Pedrito and I am looking for a petrobras employee who is my brother, he is from Dom Pedrito and is called Arley Antonio Silva if you guys can help me find him he works in Rio de Janeiro and I lost contact with him".

Users post many compliments about the company's performance on social and environmental projects. However, complaints are also common, like from this user: "We need to talk to some Social Responsibility Regional Commissioner. Here in Paraguay, there is a service station that sells alcoholic beverages that people consume on site violating several laws. We have sent several complaints and the situation persists" and this: "The truth of it all is that I never refuel at Petrobras gas stations, and I urge all people who know the truth to do the same...". The questions posted by users are seldom answered by the company.

Vivo has 15,045 recommendations from its Facebook. "We are on Facebook to get closer to you", and so begins the presentation of the company on the network. On its wall, the company posts photos, videos, invitations for events it promotes or sponsors, launches of products and services, contests, and other types of information. User comments are divided into compliments: "Congratulations Vivo, always innovating....", and complaints: "Thank you Vivo for constantly deleting a complaint that I post here about Vivo 3G without even giving me an answer! NO RESPECT FOR A PAYING CUSTOMER WHO DOES NOT HAVEA DECENT SERVICE...!". The company does not respond to complaints from users, however, users interact and provide answers to the problems raised. The company provides a customer care link, so that users and customers can ask questions, offer suggestions and make complaints. In this feature, the user is directed to the channel he or she chooses.

Vale Oportunidades is the profile of Vale on Facebook, with 7,118 user recommendations. The profile emphasizes employment opportunities in the company. The company uses

ISSN: 07 I8-2724. (http://www.jotmi.org)

Journal of Technology Management \& Innovation (c) Universidad Alberto Hurtado, Facultad de Economía y Negocios. 
the photos feature to post photo albums on their technological capacity. Other features such as Notes and Stories, are used to promote professional training programs and stories and testimonials of the company's employees. On the wall, the company places notices and communications about training programs, awards received, news about the company's performance, and announces internship openings and career opportunities. Comments from users are mostly compliments directed to the company's management.

Many posts are manifestations of users about the desire to belong to the company's employees, like this example: "Oh yeah! Really cool, I will be part of that employee figure if God allows ^.^". The company does not respond to users in Facebook, but the users themselves contribute, as the case of a user's question:"Where could we be informed about the training courses? Because I got it after the end of enrollment. May 26 at I:02 pm", to which another user responds: "Go to the Vale site and there you will find the enrollments are made online right there .... GOOD LUCK! Friday at 4:23 pm".

\section{Flickr:"share your life in pictures"}

Flickr is a social network for managing and sharing photos online, whose application allows uploading and exploring photos, and among other things, creating communities of friends, because "Flickr is made of people", therefore, it is possible to talk and learn about photos. Users upload photos and can organize them in various ways and can also name them, comment on photos of other members and also share their stories through photos: "important descriptions such as titles, tags, locations, people and more, to give context and life to your own photo" (FLICKR, 20I I).

Petrobrás joined Flickr in 2010 and is a member of $\mathrm{II}$ groups. The Canal Petrobrás Gallery has 6 albums amounting 210 shots. The photos that make up the first album, "Energy that moves the world", and the second, "Teatro Municipal do Rio de Janeiro", are the result of an international photograph competition, part of a collaborative action between the company and Lomography (community of analogue photography fans). The first album features the following caption: "driven by the challenge of understanding how the world sees and perceives energy, Petrobrás has teamed up with Lomography to look for the answer in the inspiration and talent of people around the world". The answer is presented on the LomoWallat, the Museum of Modern Art in Rio de Janeiro and shared on Flickr.

The third album, "Energy and Technology", contains photos that refer to the development of biofuel.There are pictures of labs, equipment and plants for the manufacture of biodiesel. The albums "Petrobrás Biomaps - Coast" and "Petrobrás
Biomaps - Urucu" contain photos of the Biomaps Project, an experience that, according to the company, "shows that our commitment to biodiversity also comes from the admiration and respect we have for these places" besides providing "the opportunity to know the wealth of Brazilian fauna and flora". "Valuing Culture" features pictures about the company's actions that value the preservation of cinema exhibition spaces: (I) the restoration of the Cine Odeon, located in Cinelandia (RJ) and now called Cine Odeon Petrobrás, (2) the creation of Glauber Temple, the restoration of the collection of filmmaker Glauber Rocha, and (3) the sponsoring of the project Arassussa of Araçuaí, MG.

Ambev entered Flickr in 2010. The ambevbrasil gallery has 2,131 photos in 107 albums that were grouped in 9 collections: (I) Day of responsa (a play on words with the word responsibility in Portuguese) - photos of the company's actions for the day of Responsa, part of the global campaign by the company for responsible consumption, (2) Casa Cor $201 \mathrm{I}$ - photos of the accomplishments of the company's brands in the Casa Cor event, (3) Carnival 20II - Carnival photos in different cities in which the company sponsored or promoted events, (4) Campaigns and advertising of the brands - photos of the major brand campaigns, (5) AmBev investments in Brazil - photos of investments in production capacity, (6) Ambev Recognition - awards obtained by Ambev during 2010; (7) Sponsorships of soccer clubs - AmBev brands sponsor soccer clubs throughout Brazil; (8) CYAN Movement - photos of the mobilization campaign about the importance of water conservation, launched by $A m B e v$ in March 2010, and (9) 14th Stella Artois World Draught Masters - photos from the final of Brazil phase and of the world phase of the world championship of Stella Artois Draught Masters. None of the photos was commented, though the view counter pointing that all albums were viewed.

As for the use that the two companies make of Flickr, we can observe a distinction. Petrobrás emphasized in all albums the actions of environmental and cultural responsibility, as well as their competence in developing a product that minimizes environmental impacts. Ambev, however, uses Flickr as a channel for promotion and advertising.

\section{LinkedIn: "Does your profile represent you as a professional?"”}

Linkedln is a professional network on the Internet with over 100 million users worldwide that was officially launched in March 2003 (Linkedln, 20II). On this network, members create their professional profile and become part of a professional network, they can recommend friends to recruiters, among other possibilities such as finding job placement, contact companies and recruiters and search for professionals. For members to send messages to the registered companies, they must pay for the subscription. 
The only company that uses Linkedln, among those in the group studied, is Vale. With the title "Vale Oportunidades", the company's profile has, to the date of this research, 18,081 followers and 7,635 of the company's employees are on the network. The profile of employees includes a variety of information, for example, the companies they worked for and references from other companies. In this case, the company uses the social network to attract and recruit people, besides having some surveillance over the profile of their employees.

\section{Orkut: "Same as real life"}

On Orkut, among the companies analyzed, Vale is also the only one present, joining the network in 2010 . The profile here is of a community with the same name:Vale Oportunidades, which aims to disseminate "information about career opportunities in Vale, answer questions about the selection process and discuss careers". From their profile page, users can access the Vale Opportunities channel, on their website, where interested people can register and update their resume and sign up for projects, training programs and others. There are 11,208 members in the community and 8 discussion forums, with a total of 653 posts. All posts are about questions regarding employment opportunities, internships and programs. Most posts are anonymous, but some of them send their email for contact. By reading them you can see that an interaction emerges between the various members of the community, however, there is no intervention identified as a response from the company, although some answers appear to have been posted by unidentified company employees.

Basically posts include compliments and complaints about the company, questions about selection processes and job openings. The interactions between employees and those who aspire to enter the company provide a greater picture of the company and its culture.

The description of the content of the social networks of the companies analyzed confirms the results found by McKinsey \& Company (Bughin and Manyika, 2007), regarding the purposes in the use of Web 2.0 technology by the companies. Online social networks are generally used to promote the interface with users (candidates for openings in companies, disseminating promotional material), the interface with suppliers and partners (dissemination of projects, events and promotion of the corporate image) and to manage internal collaboration (create closer ties with employees, communicate performance to shareholders).

\section{The construction of real virtual spaces: the square, the museum, the temple and the market}

Online social networks are able to leverage the renewal of organizational space, in the sense that these companies transpose into virtual space various activities of their functional areas (McAfee and Brynjolfsson, 2008), such as recruitment and selection of staff, marketing and advertising in addition to strengthening their image and identity. Our analysis, however, found that online social networks go beyond this renewal, and enhance the expansion of organizational space, changing its concept (Kornemberg and Clegg, 2005). On social networks, companies can make real virtual spaces such as the square, the temple, the museum and the market. The square is a public space, ample and open where different types of interactions occur, such as recreation. In urban areas, the square is of great importance attracting to its surroundings structures representing power, such as churches, town halls and schools. In squares people meet, get to know each other, talk, ask for information, play, live. In short, it is a place for many activities.

In this study, we identified that users of social networks interact with each other, as is the case of the Vale community in Orkut. Some of the interactions that occur on networks are similar to activities that occur in a square, such as the presentation of bands, songs, shows, and meeting friends. It is also in this space that people look for other people, exchange information, tips and live together.

Temples are buildings intended for contemplation of the sacred. A temple is the place of the divine world, the abode of the gods. This use was also observed. The companies are admired, worshiped and contemplated many times as sacred. It is in this space that companies disclose their achievements and accomplishments, their social and environmental projects, as patrons of society. Users post their admiration, and go beyond: they wish to become their faithful members.

The museum is the space for the preservation of material and artifacts symbolic of human history and all that surrounds it. Social networks are spaces where organizations keep their stories and past events that are important to their identity. The videos that tell the stories of the company, the testimony of the employees who work there, the projects done, all that is exposed on social networks much like galleries in a museum.

The market, in the sense given in this analysis, is the street market. That space where buyers and sellers meet to exchange goods. The use of social networks as a street market is also quite visible in the supply of goods, services, promotions and discounts. Marketing and advertising is one of the functional areas of business that is more evident in social

ISSN: 07 I8-2724. (http://www.jotmi.org) 
networks. Companies use this space, advertising their products, exposing their brands, their offerings and the accomplishments of their products.

We could not find a pattern common to all enterprises when considering the criteria of the social network used by them. Overall, all of them use social networks to a greater or lesser degree to make real a virtual space: a square, a museum, a temple or a street market.

\section{Final considerations}

The phenomenon of online social networking has changed the behavior of individuals, groups and organizations that use them with different objectives: to present themselves, articulate their own network of relationships and establish and maintain contact with other people. Users, initially individuals, are now also groups and organizations, and they can use social networks to interact and share content such as music, videos, photos, and more.

The use of online social networks by companies has been analyzed predominantly from the perspective of the media business. However, the use of social media goes far beyond that, because through them, organizations interact with various audiences by creating close ties of personal nature. Research that considers online social networks as an extended space, in which organizations build a "real virtuality", has not been focused by many researchers.

In this article, we illustrate how the notion of organizational space gains new contours with the adoption of online social networks with four spatial metaphors: the square, the museum, the temple and the market. These organizational spaces become real by the interactions that occur in them. Despite this possibility, the use that companies make of social networks is limited to repetitive content, not considering the circumstances and purposes of each type of social network. Moreover, we point out a certain disregard for the messages posted by users, which are mostly ignored by the companies studied during this research.

The contribution of this article is theoretical and practical, and can point out paths for researchers and organization managers. In the theoretical field, deepening the notion of what the organizational space is can spawn several studies. Among them, we suggest: analyzing the use of social networks to create organizational spaces and other potential differences between companies in different sectors. As for the practical field, this research shows managers that the use of online social networks can renew and enlarge the space where companies operate. However, the companies must recognize the characteristics and potential of each social network.

\section{References}

BOULOS, M.N.K.,Wheeler, S. (2007). The emerging Web 2.0 social software: an enabling suite of sociable technologies in health and health care education. Health Information and Libraries Journal, 24 (I), 2-23.

BROCKLEHURST, M. (200I). Power, Identity and New Technology Homework: Implications for 'New Forms' of Organizing. Organization Studies, 22 (3), 445-466.

BUGHIN, J., Manyika, J. (2007). How businesses are using Web 2.0: A McKinsey global survey. The McKinsey Quarterly. Available at: http://www.skmf.net/fileadmin/redaktion/ aktiver_content/0I_Events/0805 I4_SWISS_KM_Tool_Tag/ Track_0_Other_Material/0005_How_firms_use_Web20. pdf

CAPRIGLIONE, L. (20I I). Carência afetiva 2.0. Redes sociais exacerbam fenômeno conhecido como medo de estar perdendo algo; carentes profissionais confessam síndrome. Jornal Folha de S. Paulo, Cadernotec, FI, I8 May.

CASTELLS, M. (2007). A Sociedade em Rede. Rio de Janeiro, Paz e Terra.

COBO ROMANÍ, C., Pardo Kuklinski, H. (2007). Planeta Web 2.0. Inteligência colectiva o medios fast food. Grup de Recerca d'Interaccions Digitals, Universitat de Vic. Flacso México. Barcelona/México DF. http://docencia.izt.uam.mx/sgpe/files/ users/virtuami/file/ext/misueas_colabo_wiki_actv_aprendizajecolabo.pdf

CORNACHIONE, D. (2010). As empresas querem entrar. Revista Época, Especial Redes Sociais, 628, 92-94, 31 May.

DEMETRIO, A. (20I I). Estrelas afagam ego de usuários do Twitter. Jornal Folha de S. Paulo, Cadernotec, F6, 18 May.

DENNISON, R. (2006). Using wikis for collaboration and KM at BT. KM Review. 9(5), I.

DIJCK, J.V., Nieborg, D. (2009). Wikinomics and its discontents: a critical analysis of Web 2.0 business. New Media \& Society, I I (5), 855-876.

FAYOL, H. (1990).Administração Industrial e Geral. Previsão, organização, comando, organização e controle. São Paulo, Atlas.

GIDDENS, A. (1984). The constitution of society. Oxford, Polity Press. 
GRANJEIA, J. (20II). Pressão faz Arezzo barrar venda de pele. Jornal Folha de S. Paulo, Caderno Mercado, 19 Apr.

GROSSMAN, M. Mccarthy, R.V. (2007). WEB 2.0: is the enterprise ready for the adventure? Issues in Information Systems, VIII, 2, 180-I86. http://vc.bridgew.edu/cgi/viewcontent. cgi?article $=1010 \&$ context $=$ management_fac

HALFORD, S., Leonard, P. (2005). Place, Space and Time: Contextualizing workplace subjectivities. Organization Studies, 27(5), 657-676.

HATCH, M.J. (1999). Exploring the Empty Spaces of Organizing: How Improvisational Jazz Helps Redescribe Organizational Structure. Organization Studies, 20 (I), 75- 100.

HINCHCLIFFE. (2006). The State of Web 2.0. Web Services Journal, 4 April 4. http://web2.wsj2.com/the_state_of_ web_20.htm

HOF, R. (2006). Web 2.0 has corporate America spinning. Business Week Online, 5 Jul.

http://www.businessweek.com/technology/content/ jun2006/tc20060605_424102.htm

JFSP (20 I la). Jornal Folha de S. Paulo. Angústia vem da dificuldade de escolher. Cadernotec, F6, 18 May.

JFSP (20I Ib). Jornal Folha de S. Paulo. Mundo digital. Notas da semana. Cadernotec, 18 May.

JFSP (20I Ic). Jornal Folha de S. Paulo. Após pressão na internet, Arezzo barra venda de pele. Caderno Mercado, B4, 19 Apr.

LEE, S., Hwang, T. Lee, H. (2006). Corporate blogging strategies of the Fortune 500 companies. Management Decision, 44(3), 316-334.

McAFEE, A. (2006). Enterprise 2.0: The dawn of emergent collaboration. MIT Sloan Management Review, 47 (3), 2I-28.

McAFEE, A., Brynjolfsson, E. (2008). Investing in the IT that makes a competitive difference. Harward Business Review, Jul-Aug, I-I2.

MONTE, F. (2010). O chefe quer ser seu amigo. Revista Época, Especial Redes Sociais, 628, 88-89, 31 May.

MURUGESAN, S. (2007). Understanding Web 2.0. IEEE Computer Society. http://www.computer.org/portal/web/ csdl/doi// 0. I I09/MITP.2007.78
O'REILLY, T. (2005). Web 2.0: Compact Definition? http:// radar.oreilly.com/archives/2005/10/web_20_compact_definition.html

STARBUCK, W. (2007). Living in Mithical Spaces. Organization Studies, 28 (I), 2I-25.

TAYLOR, F.W. (1990). Princípios de Administração Científica. São Paulo, Atlas.

YOUNG, G.O. (2007). Efficiency Gains and Competitive Pressures Drive Enterprise Web 2.0 Adoption. http://www.forrester.com/Research/Document/excerpt/0,72।I,4I794,00. html 